Research Article

\title{
Thermodynamic Modeling of Solid Oxide Fuel Cell-Gas Turbine Combined Cycle Power Plant
}

\author{
M. Sreeramulu ${ }^{\dot{A}^{*}}$ and K. Deepak ${ }^{\dot{B}}$ \\ ${ }^{\dot{A}}$ Department of Mechanical Engineering, Maheshwara Engineering College, Hyderabad - 502 307, Andhra Pradesh, India. \\ ${ }^{\dot{B}}$ Department of Mechanical Engineering, Vardhaman College of Engineering, Shamshabad - 501 218, Andhra Pradesh, India
}

Accepted 10 January 2014, Available online 01 February 2014, Special Issue-2, (February 2014)

\begin{abstract}
Fuel cells offer a more efficient and fuel flexible technology that produces heat and power with lower emissions. It is observed that by integrating fuel cells with the gas turbines, more than 70\%thermal efficiency can be achieved from the combined cycle. This proves to be a better exergetic performance when compared to the conventional gas turbine plants. A Solid Oxide Fuel Cell-Gas Turbine combined cycle power plant is modeled and parametric exergy analysis is done to evaluate the energy efficiency, exergy efficiency and the exergy destruction of each component in the system. The effect of pressure ratio, turbine inlet temperature and ambient temperature on the performance of the system is investigated by using diesel and gasoline as fuels. The outcome of the modeled system reveals that SOFC and combustion chamber are the main sources of exergy destruction. At optimum pressure ratio, the total thermal efficiency using gasoline and diesel is found to be $71.36 \%$ and $70.72 \%$ while the exergy efficiency is found to be $66.53 \%$ and $66.76 \%$ respectively.
\end{abstract}

Keywords: SOFC, Gas turbine, Exergy, Exergy destruction, Combined cycle.

\section{Introduction}

High temperature fuel cells like Solid Oxide Fuel Cell and Molten Carbonate Fuel Cell have more potential to achieve higher efficiency for electricity production and are being used in USA (Williams, 2004).It is observed that pressurized SOFC increases the performance with an increase in output voltage. However the improved performance allows the integration of the SOFC with gas turbine and needs the flow of hot pressurized gas to operate. Since the SOFC stack operates at $1000^{\circ} \mathrm{C}$ it produces a high temperature exhaust gas. At elevated pressure, the hot pressurized exhaust gas can be used to drive a turbine. In SOFC-GT combined system, the compressed air needed by the fuel cell is supplied from the compressor of the gas turbine plant. The SOFC performs as combustor and the exhaust from the SOFC through combustion chamber drives the turbine and generator. Electrical Power is thus generated by the SOFC (DC) and the generator $(\mathrm{AC})$ using the same fuel and air flow. While the thermal efficiency of a conventional gas turbine plant is around 40\%, the SOFC / MCFC integrated gas turbines will have an efficiency of $56 \%-76 \%$ with varied configurations (Haseli, et al, 2008). The parametric exergy analysis of each component of the hybrid system is revealed from the literature survey (Cocco, et al, 2007).Siemens-Westinghouse power company developed the tubular SOFCs for different applications of stationary power generation. By integrating the SOFC stacks with

*Corresponding author: M. Sreeramulu

DOI: http://dx.doi.org/10.14741/ijcet/spl.2.2014.96 gas turbine and pressuring the system (PSOFC/GT), the efficiencies as high as $70-75 \%$ could be obtained (Casanova, 1988). An internal reforming hybrid SOFC/GT system could get an electrical efficiency more than 60 $\%$ (Chan, et al,2002). The SOFC/GT hybrid system can be extended to multi MW power generation system depending upon commercially available gas turbines(Song, et al, 2006). The SOFC systems were also analyzed by Calise, et al (Calise, et al, 2006). Zhang et al have presented the integration strategies for SOFCs (Zhang, et al, 2010).Douvartzideset al revealed an energyexergy analyses to optimize the operation conditions of a SOFC/GT power plant considering only hydrogen oxidation within the fuel cell and rejecting the effect of the cell losses instead of methane reforming and carbon monoxide conversion (Douvartzides, et al, 2004).Granovskii et al, have compared the performance of two combined SOFC-GT systems (Granovskii, et al, 2007). A thermodynamic exergy analysis of a combined gas turbine power system with a solid oxide fuel cell was carried by Haseli et al(Haseli, et al, 2008).The application of Yttria-stabilised zirconia cermet anodes in SOFC systems allows the conversion of methane into hydrogen and corbon monoxide on their surfaces. This consists of two simultaneous processes; conversion of methane to synthesis gas (internal reforming) and electricity generation via oxidation of the synthesized gas(Cocco, et al, 2007). The cogeneration efficiencies of fuel cell systems have also been evaluated and compared with exergy methods(Granovskii, et al, 2008).Zhu and Kee have revealed the impact of fuel utilization factor on 
SOFC efficiency using a detailed electrochemical model and generated efficiency maps which give the range of methane-steam mixtures for maximum efficiency (Zhu and Kee, 2006). The exergy analysis of combined cycle power generation unit gives the details of exergy efficiency, exergy loss and exergy destruction for individual components in the plant and also for the overall plant (Reddy and Mohammed, 2007).The pressure ratio and the turbine inlet temperature are considered as the key parameters in the analysis of combined cycle power plant (Srinivas, et al, 2006).The main objective of the present work is to investigate the performance of SOFC-GT plant using diesel and gasoline as fuels and to evaluate the exergy losses in each component of the plant. The results may be utilized for the development of efficient operating conditions of the plant.

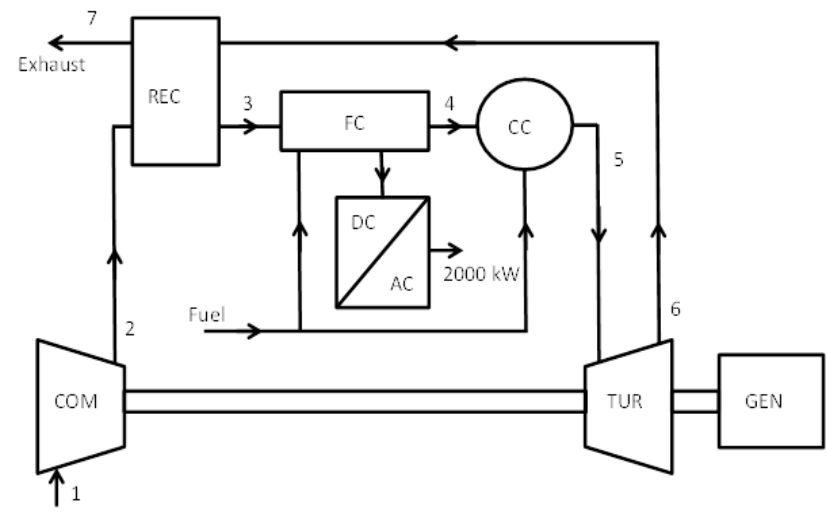

Fig. 1 Schematic flow diagram of the SOFC- GT combined cycle power generating system; REC: recuperator, FC: fuel cell, $\mathrm{CC}$ : combustion chamber, COM: compressor, TUR: turbine, GEN: Generator.

\section{Thermodynamic modeling and analysis}

Assumptions made:

Cell area, $A_{c}=834 \mathrm{~cm}^{2}$

Cell voltage, $V=0.7127 \mathrm{~V}$

Current density, $\mathrm{j}=0.3 \mathrm{~A} / \mathrm{cm}^{2}$

$\mathrm{HHV}$ of Diesel $=44800 \mathrm{~kJ} / \mathrm{kg}$

LHV of gasoline $=44400 \mathrm{~kJ} / \mathrm{kg}$

Air utilization factor, $U_{a}=25 \%$

Fuel utilization factor, $U_{f}=85 \%$

SOFC stack temp, $T_{\text {stack }}=1273 \mathrm{~K}$

$\mathrm{DC}-\mathrm{AC}$ Inverter Efficiency, $\eta_{\text {inverter }}=0.89$

DC power output from fuel cell stack $=2000 \mathrm{~kW}$

Specific chemical exergy of Diesel $=47230 \mathrm{~J} / \mathrm{kg}$

Specific chemical exergy of Gasoline $=47394 \mathrm{~kJ} / \mathrm{kg}$

The schematic flow diagram of the SOFC-GT combined cycle power generating system is shown in Fig. 1. The fuel is supplied to the SOFC and combustion chamber. The air is pressurized in the compressor, preheated in the recuperator and is supplied to the cathode of the fuel cell. The outlet air from cathode is used to burn the residual hydrogen, carbon oxide and fuel in the anode outlet gas. As the products of the chemical reaction are lean, additional fuel is injected into the combustion chamber to stabilize the combustion. The extra fuel supplied is not intended for increasing the turbine inlet temperature. The high pressure flue gas from combustion chamber is expanded in the turbine. The exhaust gas from the turbine is utilized to preheat the compressor outlet air in the recuperator. A computer program is developed to perform the analysis of the plant which consists of several control loops to calculate the thermodynamic properties of the fluid and exergy values at various state points. The effects of system parameters viz. compressor pressure ratio, turbine inlet temperature, air fuel ratio and ambient temperature on the plant performance are depicted. The following are the chemical reactions that take place generally in SOFC during power generation (Rao, et al, 2003).

Anode: $\mathrm{H}_{2}+\mathrm{O}^{2-} \rightarrow \mathrm{H}_{2} \mathrm{O}+2 e^{-}$

$\mathrm{CO}+\mathrm{O}^{2-} \rightarrow \mathrm{CO}_{2}+2 e^{-}$

Cathode: $\mathrm{O}_{2}+4 e^{-} \rightarrow 2 \mathrm{O}^{2-}$

In the current analysis, it is assumed that the fuel reacts with $\mathrm{H}_{2} \mathrm{O}$ and releases $\mathrm{H}_{2}$ and $\mathrm{CO}$. $\mathrm{CO}$ again reacts with $\mathrm{H}_{2} \mathrm{O}$ in shift and produces $\mathrm{H}_{2}$. The heat required for reformer is supplied by the SOFC. Ideal voltage values for an intermediate temperature SOFC operating at $800^{\circ} \mathrm{C}$ and $1100^{\circ} \mathrm{C}$ are $0.99 \mathrm{~V}$ and $0.91 \mathrm{~V}$ respectively (Uechi, et $a l, 2004)$.The thermodynamic performances of all the components of the system are analyzed using the following governing equations.

2.1 SOFC

The rate of heat production due to irreversibilities (Zhang, et al, 2010)

$Q_{g e n, F c}=P_{e l e, D C}\left[\left(\frac{1.25}{V_{c}}\right)-1\right] \times 10^{-6}$

, $\mathrm{kW}$

Mass flow rate of air

$m_{a, F C}=3.57 \times 10^{-7} \times \lambda \times \frac{P_{e l e, D C}}{V_{c}}, \mathrm{~kg} / \mathrm{s}$

Physical exergy

$E_{x, p h y}=m C_{p}\left[\left(T-T_{0}\right)-T_{0} \ln \left(\frac{T}{T_{0}}\right)\right]+R T_{0} \ln \left(\frac{P}{P_{0}}\right)$

Chemical exergy

$E_{x, \text { chemical }}=m R T_{\mathrm{o}} \sum x_{i} \ln \left(\frac{x_{i}}{y_{i}}\right)$

Irreversibility of the combustion reaction

$I_{F C}=T_{0}\left[\left\{\left(S_{p}\right)_{4}-\left(S_{p}\right)_{0}\right\}-\left\{\left(S_{a}\right)_{3}-\left(S_{a}\right)_{0}\right\}+\left\{(\Delta S)_{\text {reaction }}\right\}_{0}\right]$

$T_{\mathrm{o}}(\Delta S)_{r x n}=m_{f c}(L H V)_{f}(\Phi-1)$

by energy balance(Calise, et al, 2007)

$m_{3} h_{3}=m_{f f c} \times U_{f} \times L H V+m_{f f c} \times\left(1-U_{f}\right) h_{f}, i n-P_{e l e, D C}-m_{4} h_{4}=0$

By exergy balance (Calise, et al, 2007)

$\eta_{e x, F C}=\frac{P_{e l e, D C}}{\left[m_{f f c} \times\left(\Psi_{f m}+\Psi_{f t}\right)+m_{f f c} \times U_{f} \times \Psi_{c h, f}\right]-\left[m_{4} \Psi_{4}-m_{3} \Psi_{3}\right]}$

\subsection{Combustion Chamber}

by energy balance 
$\left(m_{3}+U_{f} \times m_{f f c}\right) h_{4}+Q_{\text {combustion }}-m_{5} h_{5}-Q_{\text {loss }}=0$

where

$Q_{\text {combustion }}=\left[m_{f f c} \times\left(1-U_{f}+m_{f f c}\right)\right] \times L H V$

$Q_{\text {loss }}=\left[m_{f f c} \times\left(1-U_{f}\right)+m_{f f c}\right] \times\left(1-\eta_{\text {combustion }}\right) \times L H V$

(14)

By exergy balance irreversibility in combustion chamber

$I_{C C}=\left[\left\{\left(S_{p}\right)_{5}-\left(S_{p}\right)_{0}\right\}-\left\{\left(S_{a}\right)_{4}-\left(S_{a}\right)_{0}\right\}+\left\{(\Delta S)_{r x n}\right\}_{0}\right]$

Exergy efficiency

$\eta_{e x, C C}=\frac{m_{5} \Psi_{5}-m_{4} \Psi_{4}}{m_{f f c} \times\left(1-U_{f}\right) \Psi_{c h, f}+m_{f c c}\left(\Psi_{p h f}+\Psi_{c h f}\right)} \times 100$

\subsection{Compressor}

Irreversibility in the compressor

$$
I_{\text {compressor }}=T_{0}\left(S_{2}-S_{1}\right)
$$

Exergy efficiency

$$
\eta_{\text {compressor }}=\frac{m_{1}\left(\psi_{2}-\psi_{1}\right)}{m_{1}\left(h_{2}-h_{1}\right)} \times 100
$$

\subsection{Recuperator}

Irreversibility in the recuperator

$I_{\text {recuperator }}=m_{6}\left(\Psi_{6}-\Psi_{7}\right)-m_{2}\left(\Psi_{3}-\Psi_{1}\right)$

Exergy efficiency

$\eta_{\text {ex }, \operatorname{Rec}}=\frac{m_{2}\left(\Psi_{3}-\Psi_{2}\right)}{m_{6}\left(\Psi_{6}-\Psi_{7}\right)}$

\subsection{Gas Turbine}

Rate of exergy loss in the gas turbine

$I_{\text {gasturbine }}=m_{5} \times T_{0} \times\left(S_{5}-S_{6}\right)$

Exergy efficiency

$\eta_{\text {gasturbine }}=\frac{W_{\text {gasturbine }}}{m_{5}\left(\Psi_{5}-\Psi_{6}\right)} \times 100$

\subsection{Performance of the plant}

Total net power develop by the system

$$
P_{n e t}=P_{F C, A C}+P_{g e n}
$$

The total thermal efficiency of the cycle

$\eta_{\text {th,cycle }}=\frac{P_{\text {net }}}{Q_{\text {tot }}} \times 100$

The exergy efficiency of the cycle

$$
\eta_{\text {ex,cycle }}=\frac{P_{n e t}}{m_{f}\left(\Psi_{f m}+\Psi_{f t}+\Psi_{f, c h}\right)} \times 100
$$

\section{Results and discussion}

The variation of cycle and exergy efficiency with the variation of pressure ratio is depicted in Fig. 2 and Fig. 3.

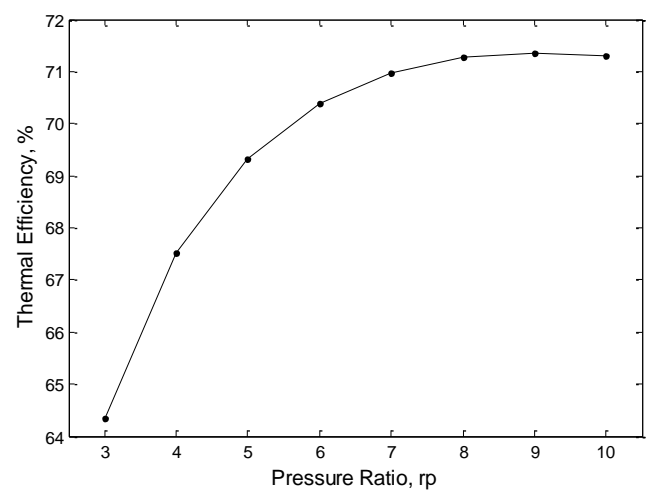

Fig. 2 Variation of cycle thermal efficiency with pressure ratio

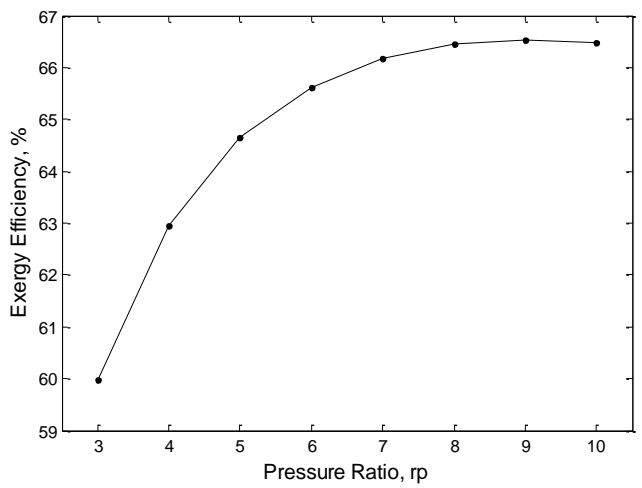

Fig.3Variation of cycle exergy efficiency with pressure ratio

The thermal and exergy efficiencies increase with the pressure ratio up to 9 and then decrease. Using gasoline as fuel, at optimum pressure ratio9the total thermal efficiency and the exergy efficiency is found to be $71.36 \%$ and $66.53 \%$. Similarly using diesel as fuel, at the optimum pressure ratio 9 the total thermal and exergy efficiencies are found to be $70.72 \%$ and $66.76 \%$ respectively. Fig. 4 presents the variation of net power output from the gas turbine with the pressure ratio.

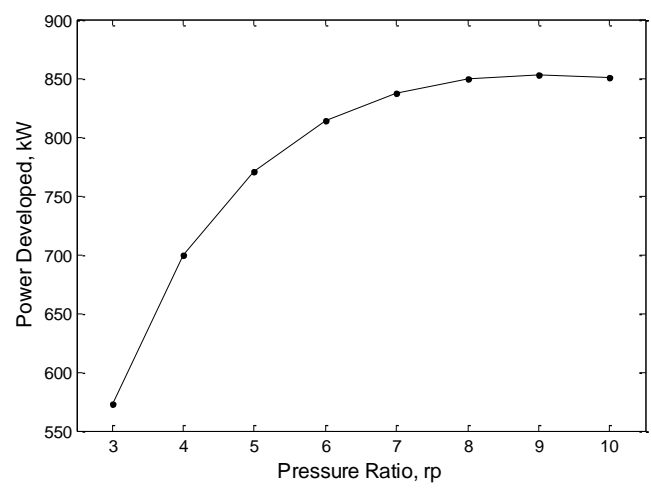

Fig.4 Effect of the pressure ratio on net power developed by the generator 
The increase in power output is due to the higher cell e. $\mathrm{m}$. f. The maximum net power output is $853.29 \mathrm{~kW}$ at the optimum pressure ratio 9 . The difference between enthalpy of reaction and cell electrical output is the heat energy available for raising the temperatures of input fuel gas and air in fuel cell up to the cell operating temperature. The greater the heat for raising the temperature of gas and air streams, the more is the exergy loss.

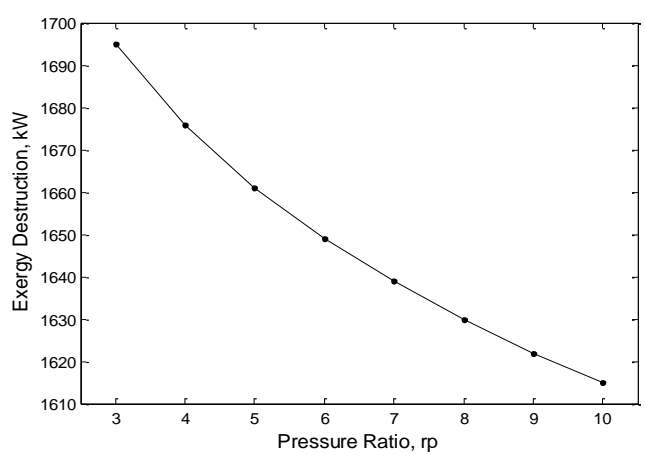

Fig.5 Effect of the pressure ratio on exergy destruction of the system

With higher pressure ratio, this heat decreases as the difference between fuel cell operating temperature and the temperature of air to the fuel cell decreases. Hence, the exergy loss decreases and exergetic efficiency increases. Fig. 5 depicts the variation of exergy destruction with the increase in pressure ratio due to increase irreversibilities in all the components particularly in combustion chamber and fuel cell. At higher pressure ratio, the electrochemical reaction in the fuel cell increases resulting in less combustibles for combustion in combustion chamber. Hence, the exergy destruction due to chemical reaction in combustion chamber decreases at higher pressure ratio. As a result, the exergy loss decreases and exergetic efficiency increases for combustion chamber with higher pressure ratio. With increase in pressure ratio, the temperature of the exhaust gas form the gas turbine decreases. Hence, at high pressure ratio, the heat transfer in the recuperator occurs at low temperature difference. This gives lower exergy loss at high pressure ratio in the recuperator. Fig.6 and 7 show the variation of thermal and exergy efficiency with the turbine inlet temperature. The efficiencies increase with increase in turbine inlet temperature.

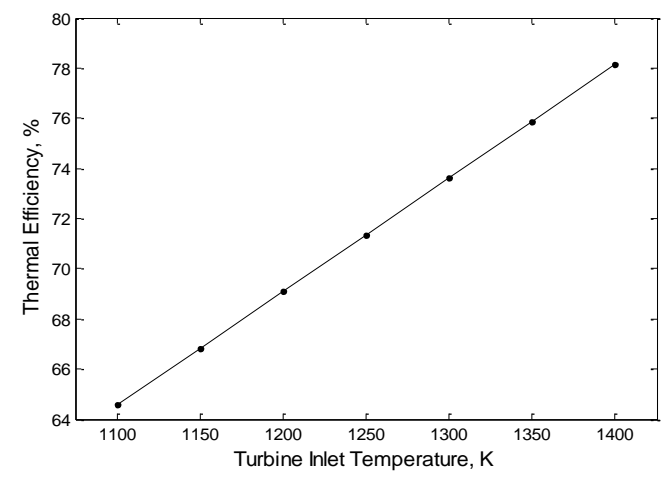

Fig.6 Effect of the turbine inlet temperature on thermal efficiency of the system
It is due to the utilization of exergy of unburnt fuel from the fuel cell and the additional supply of fuel in the combustion chamber. In Fig.8 the variation of net power developed by the gas turbine with the turbine inlet temperature is presented. The increase in power output requires higher fuel flow rate which leads to the increase in total exergy destruction. So power output from turbine can be controlled by adjusting air fuel ratio.

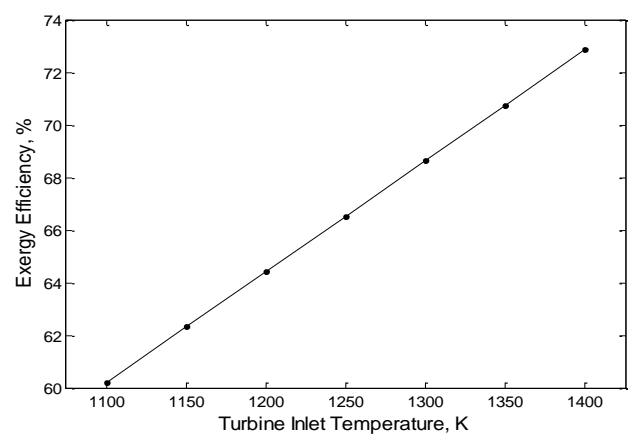

Fig.7 Effect of the turbine inlet temperature on exergy efficiency of the system

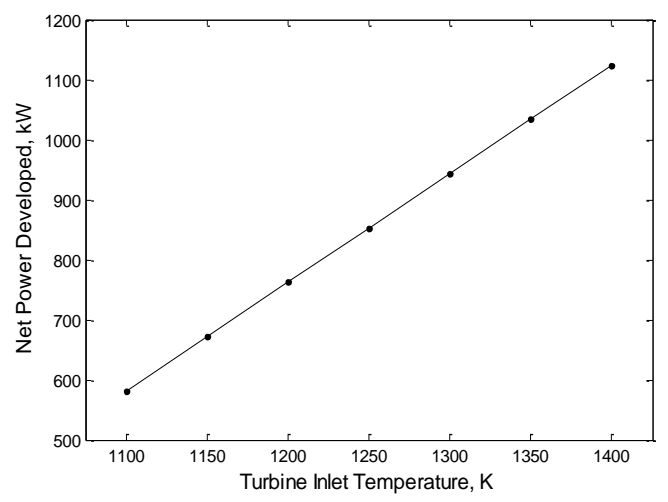

Fig. 8: Effect of the turbine inlet temperature on net power developed by the generator.

The variation of exergy destruction with the turbine inlet temperature is presented in Fig. 9.Both the exergy destruction and net power output from the turbine as well are found to increase with increase in turbine inlet temperature. This is due to the fact that the temperature of the working fluid in the gas turbine is high. Power output of about 30 to $50 \%$ of fuel cell power can be obtained from the generator. The effect of increase in ambient temperature on the variation of efficiency is depicted in the Fig. 10.

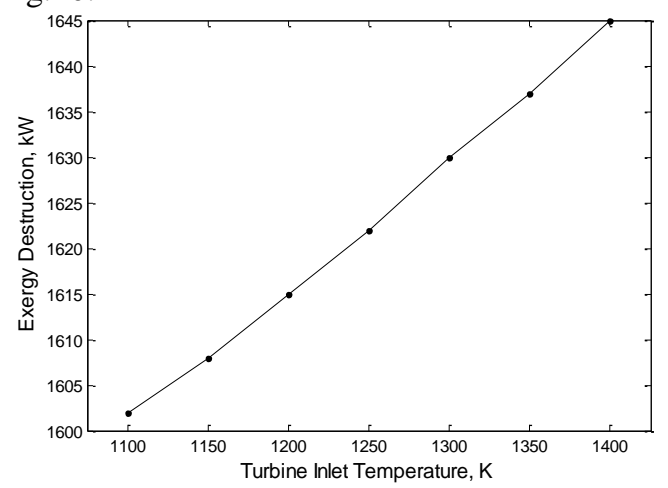

513 | International Conference on Advances in Mechanical Sciences 2014 
Fig.9 Effectof Turbine inlet temperature on exergy destruction of the system

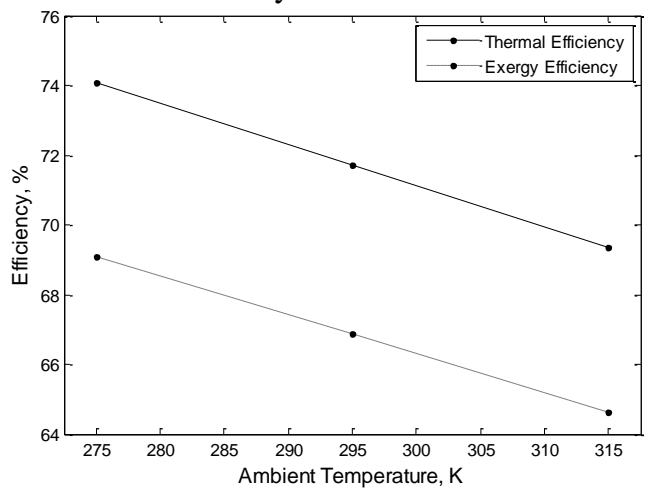

Fig.10 Effectof the ambient temperature of air on thermal and exergy efficiency of the system

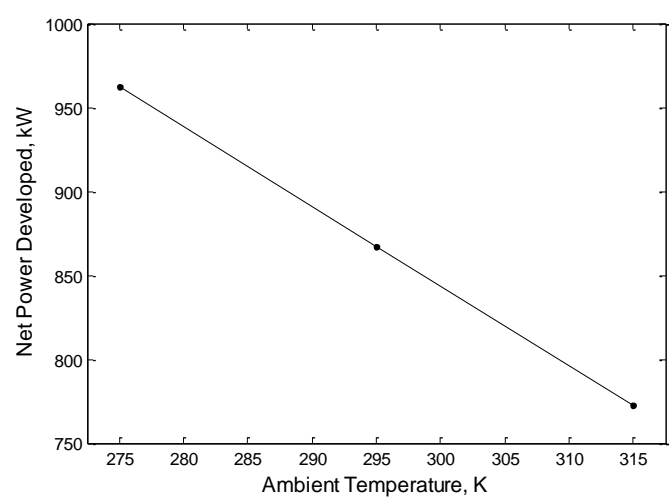

Fig.11 Effect of the ambient temperature of air on net power developed by the generator.

Due to higher power requirements, the cycle efficiency decreases with an increase in ambient temperature.Fig.11 presents the variation of net power developed by the gas turbine with the ambient temperature of air. The net power output from the gas turbine is decreases by $106 \mathrm{~kW}$, for every $20^{\circ} \mathrm{C}$ increase in the ambient temperature. The maximum exergy destruction occurs in the SOFC and combustion chamber irrespective of the type of fuel used. This is due to the high temperature of the working fluid, chemical reactions and a small pressure drop. At the optimum pressure ratio of 9, the maximum exergy destruction is found to be $1622 \mathrm{~kW}$ for gasoline and 1594 $\mathrm{kW}$ for diesel. Fig.12 shows the exergy of working fluid in each component of the system.

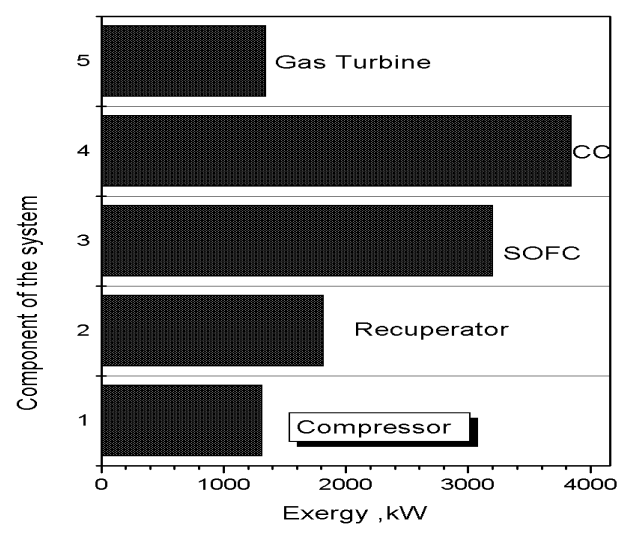

Fig.12 Exergy of working fluid in each component of the system.

Table 1Comparison of performance of SOFC-GT power generating system with diesel and gasoline fuels

\begin{tabular}{|l|l|l|}
\hline \multirow{2}{*}{ Particulars } & \multicolumn{2}{|l|}{ Fuel used } \\
\cline { 2 - 3 } & Diesel & Gasoline \\
\hline Thermal efficiency & $70.72 \%$ & $71.36 \%$ \\
\hline Exergy efficiency & $66.76 \%$ & $66.53 \%$ \\
\hline Exergy Destruction & $1594 \mathrm{~kW}$ & $1622 \mathrm{~kW}$ \\
\hline
\end{tabular}

\section{Conclusion}

1) Combined cycle power plants have higher efficiency than those of recuperated conventional gas turbine plants because the exergy losses of combustion are minimized.

2) An increase in pressure ratio results in lower rate of exergy destruction of the plant, which increases the total thermal and exergy efficiency of the system.

3) The increase in turbine inlet temperature and ambient temperature yields higher rate of exergy destruction of the plant.

4) The generating efficiency peaks at a particular pressure ratio, but the variation of pressure ratio near the optimum point does not lead to a remarkable difference.

5) The exergy destruction in fuel cell is highest compared to other components in the system, though it is an efficient device.

6) Exergy analysis of each component provides better understanding of losses at various states of the system.

7) Gasoline gives higher energy and exergy efficiencies compared to diesel.

8) Diesel fueled SOFC-GT hybrid systems are more clean and efficient energy solutions compared to internal combustion engines for electrical power generation.

\section{Nomenclature}

specific exergy fuel $(\mathrm{kJ} / \mathrm{kg})$

I exergy destruction rate $(\mathrm{kW})$

HHV higher heating value $(\mathrm{kJ} / \mathrm{kg})$

$h \quad$ enthalpy $(\mathrm{kJ} / \mathrm{kg})$

I current (mA)

$j \quad$ current density $(\mathrm{mA} / \mathrm{cm} 2)$

LHV lower heating value $(\mathrm{kJ} / \mathrm{kg})$

$\mathrm{m} \quad$ mass flow rate $(\mathrm{kg} / \mathrm{s})$

$P \quad$ pressure $(\mathrm{kPa})$

Q heat transfer rate $(\mathrm{kW})$

$\mathrm{Q}_{G e n, F C}$ heat generation rate within the cell stack $(\mathrm{kW})$

$R \quad$ universal gas constant $(8.314 \mathrm{~J} / \mathrm{mole} \mathrm{K})$

$T \quad$ temperature $(\mathrm{K})$

To reference temperature $(\mathrm{K})$

W power $(\mathrm{kW})$

$\mathrm{W}_{\mathrm{FC}, \mathrm{dc}} \quad$ DC power output of the cell stack $(\mathrm{kW})$

Wnet net power output of the plant $(\mathrm{kW})$

$\lambda \quad$ Stoichiometric constant 


$\begin{array}{ll}\text { Subscript } & \\ \text { act } & \text { activation } \\ \text { cyc } & \text { Cycle } \\ \text { c } & \text { Cell } \\ \text { Comb } & \text { combustion chamber } \\ \text { Conc } & \text { concentration } \\ \text { ch,f } & \text { chemical exergy of fuel }(\mathrm{kJ} / \mathrm{kg}) \\ \text { Ex } & \text { exergy } \\ \text { FC } & \text { fuel cell } \\ \text { fm } & \text { mechanical exergy of fuel }(\mathrm{kJ} / \mathrm{kg}) \\ \text { Gen } & \text { generator } \\ \text { In } & \text { inlet } \\ \text { Ohm } & \text { ohmic } \\ \text { Out } & \text { outlet } \\ \text { Ph,f } & \text { physical exergy of fuel }(\mathrm{kJ} / \mathrm{kg}) \\ \text { th,f } & \text { thermal exergy of fuel }(\mathrm{kJ} / \mathrm{kg}) \\ \text { th } & \text { thermal }\end{array}$

\section{References}

M.C.Williams,(2004), Fuel Cell Handbook, 7th edition, $E G \& G$ Technical Services, Inc. Morgantown, West Virginia.

Y.Haseli, I.Dincer, G.F.Naterer,(2008), Thermodynamic modeling of a gas turbine cycle combined with a solid oxide fuel cell, International Journal of Hydrogen Energy 33, pp. 5811-5822.

D.Cocco and V.Tola,(2007), Comparative performance analysis of internal and external reforming of methanol in SOFC-MGT hybrid power plants, ASME Journal of Engineering for Gas Turbines and Power 129, 2, pp. 478-487.

A. D. Rao and G.S.Samuelsen,(2003), A thermodynamic analysis of tubular solid oxide fuel cell based hybrid systems, transactions of the ASME, J.Engg.Gas Turbines and Power 125, 1, pp.59-66.

Casanova,A.,(1998), A consortium approach to commercialized westing house solid oxide fuel cell Technology, Journal of Power Sources, 71, pp.65-70.

Chan,S.H.,H.K.Ho and Y.Tian,(2002), Modelling of simple hybrid solid oxide fuel cell and gas turbine power plant, J.Power Sources, 109, pp.111-120.

Song,T.W., J.L.Sohn, T.S.Kim, and S.T.Ro,(2006), Performance characteristics of a MW-Class SOFC/GT hybrid system based on a commercially available gas turbine, J.Power Sources, 158, pp.361-367.
Calise,F., M.D.Accadia, M.L.Vanoli and M.R.VonSpakovsky,(2006), Single-level optimization of a hybrid SOFC/GT power plant, Journal of Power Sources, 159, pp.1169-1185.

Calise,F., M.D.Accadia, M.L.Vanoli and M.R.VonSpakovsky,(2007), Full load synthesis/design optimization of a hybrid SOFC/GT power plant. Energy, 31, pp.446-458.

Zhang, X,S.H.Chan,G.Li,H.K.Ho,J.Li and Z.Feng,(2010). A review of integration strategies for solid oxide fuel cells J.Power Sources, 195, pp.685-702.

Douvarttzides,S., Coutelieris,F.,Tsiakaras,P., (2004), Exergy analysis of a solid oxide fuel cell power plant fed by either ethanol or methane, Journal of Power Sources,131, pp.224230.

Granovskii, M.,I. Dincer and M.A.Rosen, (2007). Performance comparison of two combined SOFC-Gas turbine systems, J.PowerSources, 165, pp.307-314.

Haseli.Y.,I.Dincer and G.F.Naterer,(2008), Thermodynamic analysis of combined gas turbine power system with a solid oxide fuel cell through exergy.ThermochimicaActa, 480, 1-9

Companari,S., (2001), Thermodynamic model and parametric analysis of a tubular sofc module, Journal of Power Sources, 92, pp.26-34.

Granovskii,M.,I.Dincer and M.ARosen, (2008),Exergy analysis of gas turbine cycle with steam generation for methane conversion within solid oxide fuel cells, ASME J.Fuel Cell Sci.Technol., 5(3),p.03, 1005

Zhu,H., and Kee,R.J., (2006),Thermodynamics of SOFC efficiency and fuel utilization as function of fuel mixtures and operating conditions, Journal of Power Sources ,161, pp.957964.

Reddy,B.V.and Mohammed, K., (2007), Exergy analysis of a natural gas fired combined cycle power generation unit Int.J.Exergy,Vol.4,No.2, pp.180-196.

Srinivas, T., Gupta, A.V.S.S.K.S., Reddy, B.V., and Nag,P.K., (2006), Parametric analysis of a coal based combined cycle power plant. Int.J.Energy Res.,30(1), pp. 19-36.

H.Uechi, Sh.Kimijima, N.Kasagi, (2004), Cycle analysis of gas turbine-fuel cell cycle hybrid micro generation system, ASME Journal of Engineering for Gas Turbines and Power 126, 4, pp. 755-762. 